\title{
H2 super: inovasi pupuk organik cair dari sampah pasar H2, Desa Sido Mukti, Kecamatan Gedung Aji Baru
}

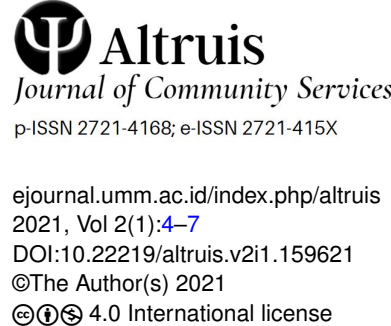

\author{
Fattur Rachman ${ }^{1}$, Erninda Octalyani ${ }^{1}$, Ardan Maulana ${ }^{1}$, Naufal Dani Fauzan ${ }^{1}$, Izzah Safina \\ An-Najjah ${ }^{1}$
}

\begin{abstract}
H2 Market is a traditional market located in Sido Mukti Village, Gedung Aji Baru District, Tulang Bawang Regency. This market already has landfills in every corner of the market, however, until now the organic waste has only been disposed of and has not been used properly. For this reason, the focus of this community service is the management of market $\mathrm{H} 2$ organic waste into liquid organic fertilizer which can fertilize plants and have economic value. The main materials used are market waste, clean water, EM-4 decomposer, and sugar water. Participants showed a very positive response and participated actively in outreach activities. After the counseling ended, participants were given an instruction sheet for making liquid organic fertilizer so that they can be practiced at home. With this innovation, it is hoped that participants will be able to use the organic waste to become liquid organic fertilizer which can increase soil fertility as well as become a typical product of Sido Mukti Village which has economic value and can be marketed through BUMDes (Village-Owned Enterprises).
\end{abstract}

\section{Keywords}

Market, Liquid Organic Fertilizer, Waste

\section{Pendahuluan}

Desa Sido Mukti merupakan salah satu Desa yang berada di Kecamatan Gedung Aji Baru, Kabupaten Tulang Bawang, Provinsi Lampung. Kecamatan Gedung Aji Baru memiliki 3 pasar di Desa Makarti Tama, Desa Suka Bhakti dan Desa Sido Mukti namun, pasar induk Kecamatan Gedung Aji Baru berada di Desa Sido Mukti sehingga banyak sekali sampah organik di Pasar ini yang belum dimanfaatkan dengan maksimal.

Latifah et al. (2012) mengemukaan bahwa sampah pasar terutama sampah organik, apabila tidak dikelola dengan baik dan benar, maka akan menimbulkan pencemaran lingkungan. Sampah organik dari pasar masih mengandung kadar air yang tinggi serta mengandung bahan-bahan organik yang kaya akan unsur hara yang dapat menyuburkan tanah. Salah satu cara yang dapat dilakukan untuk mengelola sampah pasar ialah dengan membuat sampah pasar tersebut menjadi pupuk organik cair yang cepat meresap ke dalam tanah dan cepat dimanfaatkan langsung oleh tanaman. Dalam pembuatan pupuk organik cair perlu adanya penambahan cairan gula karena menurut Hadisuwito (2007), dengan penambahan gula dalam bentuk cair untuk membuat pupuk organik cair, mikroorganisme pengurai bahan organik akan dapat bekerja dengan maksimal. Hal ini dikarenakan gula mengandung glukosa sebagai sumber energi dari mikroorganisme.

Sebagian besar warga di Desa Sido Mukti bekerja di bidang pertanian mulai dari buruh pabrik di perusahaan kelapa sawit, petani kelapa sawit, petani sawah, maupun petani perkebunan sayur mayur. Namun walaupun bekerja di bidang pertanian, masyarakat tidak pernah mengaplikasikan pupuk organik cair. Hal ini dikarenakan masyarakat belum tahu bagaimana cara membuat pupuk organik cair sekaligus harga pupuk organik cair di pasaran juga cukup tinggi. Desa Sido Mukti sendiri memiliki BUMDes (Badan Usaha Milik Desa) namun sampai saat ini, Desa Sido Mukti belum memiliki satupun produk khas dari Desa ini. Untuk itu pengabdian masyarakat ini memiliki tujuan untuk mengelola sampah organik di Pasar H2 Desa Sido Mukti, menjadi pupuk organik cair yang dapat menyuburkan lahan pertanian sekaligus menjadi produk bernilai ekonomis yang dapat di pasarkan melalusi BUMDes.

Pupuk organik cair merupakan pupuk organik dalam bentuk cair yang dibuat menggunakan proses fermentasi oleh mikroorganisme dan menggunakan bahan ataupun sampah organik. Selain dapat mengurangi pencemaran lingkungan akibat sampah organik, menurut Salam (2012), pupuk organik cair yang merupakan salah satu pupuk organik yang mengandung berbagai macam unsur hara makro primer (seperti $\mathrm{N}, \mathrm{P}, \mathrm{K})$, makro sekunder $(\mathrm{Ca}, \mathrm{Mg}, \mathrm{S})$ maupun mikro yang sangat dibutuhkan oleh tanaman.

Menurut Marsiningsih (2014) pupuk organik cair memiliki banyak manfaat dalam memperbaiki kesuburan tanah

${ }^{1}$ Mahasiswa Kuliah Kerja Nyata (KKN) Periode I, Tahun 2020,
Universitas Lampung

\section{Korespondensi:}

Fattur Rachman, Mahasiswa Kuliah Kerja Nyata (KKN) Periode I, Tahun 2020, Universitas Lampung

Email: fatturrachman99@gmail.com 
antara lain dapat menjadi sumber hara tanaman yang cukup lengkap ( $N, P, K, C a, M g, S$, serta hara mikro) dalam jumlah tidak tentu dan relatif kecil, memperbaiki kehidupan biologi tanah (terutama mikro fauna tanah) karena ketersediaan makan lebih terjamin, dapat meningkatkan daya sangga tanah serta dapat meningkatkan kemampuan dekomposisi bahan organik tanah karena pupuk organik cair mengandung banyak mikroorganisme yang dapat membantu mempercepat proses dekomposisi bahan organik.

Pupuk organik cair yang dibuat masyarakat Desa Sido Mukti selain dapat memanfaatkan limbah organik yang bisa mencemari lingkungan, diharapkan dapat membantu membangun desa di bidang pertanian dan mengurangi penggunaan pupuk anorganik bagi petani. Berkurangnya penggunaan pupuk anorganik bagi petani berarti mengurangi biaya produksi pertanian sekaligus menyuburkan tanah. Selain itu dari sudut pandang ekonomi, diharapkan pembuatan pupuk organik cair di Desa ini dapat berkelanjutan dan menjadi produk khas di desa ini dan dapat di jual di Desa ataupun daerah lain.

\section{Metode}

Kegiatan bina desa ini dilakukan sejak bulan JanuariFebruari 2020 (sebelum pandemi Covid-19 menyebar di Indonesia) di Desa Sido Mukti, Kecamatan Gedung Aji Baru, Kabupaten Tulang Bawang. Bahan yang digunakan dalam proses pembuatan pupuk organik cair adalah sampah pasar, air bersih, dekomposer EM-4, dan air gula. Alat yang digunakan adalah wadah tertutup.

Sebelum dilakukan penyuluhan, dilakukan peninjauan terkait sampah pasar yang ada di Desa Sido Mukti dan pengetahuan masyarakat terkait pupuk organik cair dari cara membuat hingga memanfaatkannya. Selanjutnya dilakukan pencarian bahan dan alat sebelum dilakukan penyuluhan pembuatan pupuk organik cair.

Penyuluhan yang dilakukan adalah penjelasan terkait manfaat pupuk organik dan praktek pembuatan pupuk organik cair bersama warga (Kegiatan penyuluhan sebagaimana Gambar 1 dan Gambar 2). Setelah selesai dilakukan pembagian materi yang sudah dicetak dalam lembar kertas.

Setelah penyuluhan, dilakukan peninjauan sejauh mana pengetahuan peserta dalam memanfaatkan limbah organik menjadi pupuk organik cair. Dan dilakukan kembali penyuluhan desain sederhana untuk mengemas produk pupuk organik cair. Hasil pengolahan sampah pasar yang telah menjadi pupuk organik cair selain dapat dijual, dapat pula digunakan kembali untuk warga untuk meningkatkan kesuburan tanaman warga.

\section{Hasil}

\section{Peninjauan Sampah Pasar dan Pengetahuan Masyarakat}

SPeninjauan sampah pasar dilakukan untuk mengetahui kuantitas sampah organik yang ada di pasar H2 Desa Sidomukti. Berdasarkan hasil peninjauan di lokasi, dapat diketahui bahwa pasar H2 Desa Sido Mukti sudah memiliki tempat pembuangan sampah namun, sampah organik yang ada di desa ini belum dimanfaatkan menjadi sesuatu yang bernilai ekonomis.
Selanjutnya kami melakukan kunjungan ke rumah Ibu Yuniati, A.Ma. selaku Kepala Desa Sido Mukti untuk menyampaikan program penyuluhan Pembuatan Pupuk Organik Cair. Dalam penyampaian program ini turut hadir perangkat desa beserta ketua kelompok tani untuk menanggapi acara tersebut. Dari uraian mereka diketahui bahwa masih banyak petani yang belum mengetahui cara membuat pupuk organik cair. Selain itu, Ibu Yuniati, A.Ma. menyampaikan bahwa Desa Sido Mukti memiliki BUMDes namun sampai saat ini belum memiliki produk khas Desa Sido Mukti. Untuk itu, Ibu Yuniati berharap pupuk organik cair ini dapat menjadi produk khas Desa Sido Mukti.

\section{Penyuluhan Pembuatan Pupuk Organik Cair dari Sampah Pasar}

Sebelum dilakukan penyuluhan pembuatan pupuk organik cair, peserta dikenalkan dengan pupuk organik cair dan dijelaskan terlebih dahulu manfaat dari pupuk organik cair. Pupuk organik cair adalah pupuk organik dalam bentuk cair yang ditambahkan ke dalam tanah untuk meningkatkan kesuburan tanah karena menurut Rahmah et al. (2014), pupuk organik cair ini mampu meningkatkan aktifitas biologi, kimia maupun fisika tanah. Namun, sampai saat ini masih banyak petani yang masih bergantung dengan pupuk anorganik. Padahal menurut Indriani (2004) meskipun pupuk anorganik memiliki kandungan hara yang lebih tinggi, jika pupuk anorganik digunakan terus menerus maka akan berdmpak terhadap penurunan status kesuburan tanah dan menyebabkan hasil panen menurun.

Selanjutnya diberikan praktek pembuatan pupuk organik cair. Praktek ini dilakukan agar peserta lebih memahami

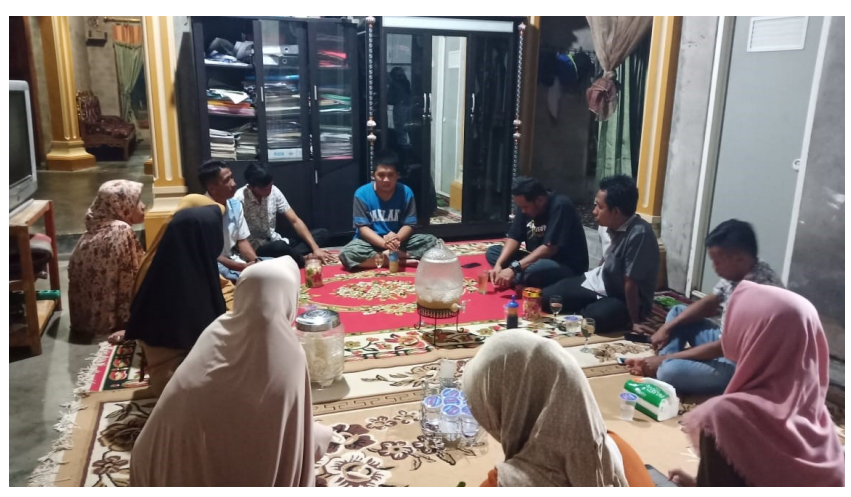

Gambar 1. Penyampaian Program Penyuluhan dengan Perangkat Desa

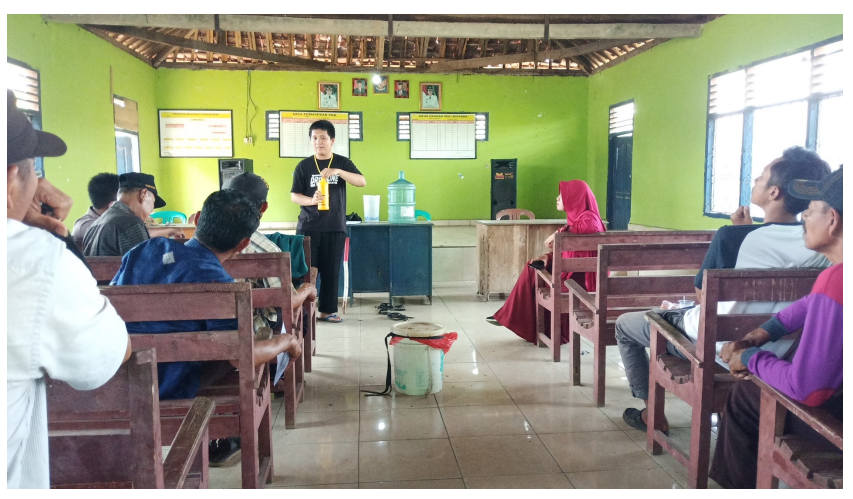

Gambar 2. Penjelasan Terkait Pupuk Organik Cair 


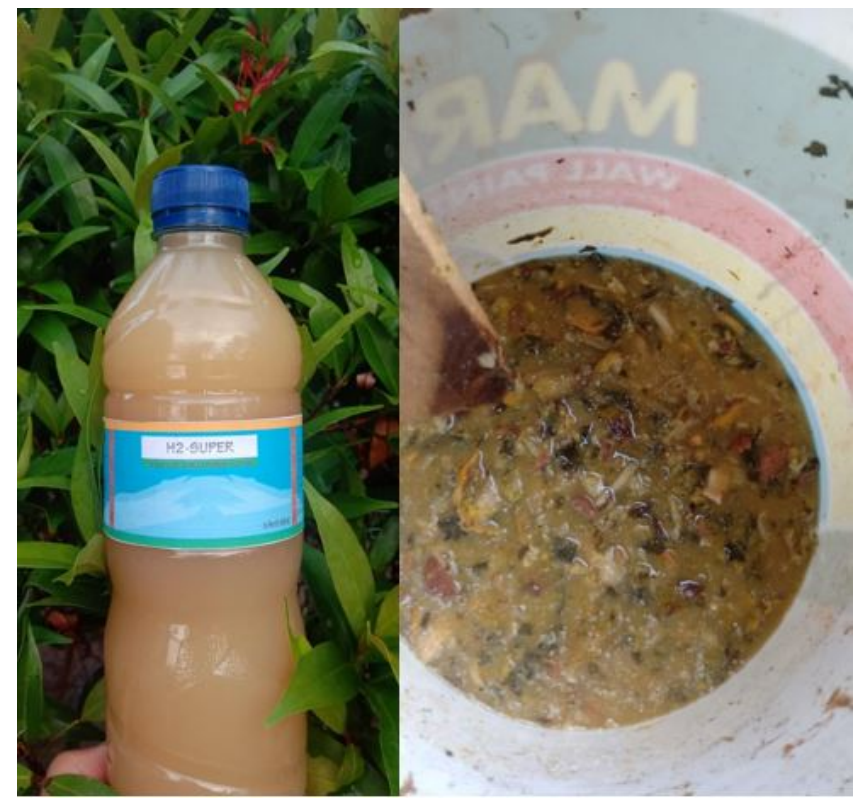

Gambar 3. Kemasan pupuk organik cair H2 Super (kiri) dan pupuk organik cair yang dibuat peserta

tentang proses proses pembuatan pupuk organik cair. Dalam proses penyuluhan, disela materi yang diberikan diberikan pertanyaan dalam beberapa waktu untuk menilai minat dan daya tangkap peserta terhadap materi yang diberikan. Disini dapat dilihat peserta menunjukan respon yang sangat positif terhadap materi yang diberikan. Setelah penyuluhan selesai peserta diberikan lembar petunjuk pembuatan pupuk organik cair.

\section{Peninjauan Peserta Pasca Penyuluhan}

Setelah pelatihan peserta dalam wadah kelompok tani membuat pupuk organik cair di rumah ketua kelompok tani desa Sido Mukti berdasarkan lembar petunjuk yang dibagikan. Setelah 14 hari proses fermentasi dapat dilihat bahwa pupuk organik cair yang peserta buat telah berhasil dengan baik karena pupuk organik cair tersebut tidak berbau busuk dan mengeluarkan bau seperti tapai. Hal ini sesuai dengan pendapat Kasmawan et al. (2017) yang menyatakan ciri pupuk organik cair yang sudah terdekomposisi memiliki bau seperti tapai. Hasil pembuatan pupuk oleh warga seperti pada Gambar 3.

Peserta yang sebagian besar terdiri dari petani sangat senang dengan pupuk organik cair karena pemakaian pupuk organik cair yang relatif lebih mudah dibandingkan pupuk organik padat. Hal ini sesuai pernyataan Rohani et al. (2017) yaitu keunggulan penggunaan pupuk organik cair yaitu kuantitas penggunaan lebih hemat dibandingkan dengan menggunakan pupuk organik padat. Selain itu, proses aplikasinya akan lebih mudah karena dapat diberikan dengan penyemprotan atau penyiraman secara langsung pada tanah.

Sampah pasar yang terdiri dari bahan organik didekomposisi oleh mikroba mikroba melalui proses dekomposisi. Menurut Latifah et al. (2012) proses dekomposisi bahan organik ini diawali dengan adaptasi mikroorganisme terhadap lingkungan dan membentuk koloni dalam tumpukan sampah organik tersebut. Pada tahap selanjutnya, muncul jasad renik dari golongan Mesofilia yang berperan aktif dalam memecah dan menghancurkan bahan organik yang ada. Setelah penghancurkan bahan organik, terjadi stabilisasi sampah dan banyak terjadi pengurangan bakteri Mesofilia karena peningkatan suhu yang drastis. Selain itu juga disertai munculnya mikroorganisme termofilik, seperti fungi dan Actynomicetes. Mikroorganisme termofilik biasanya muncul 5-10 hari setelah proses dekomposisi. Pada akhir proses dekomposisi bakteri Mesofilia sudah tidak ditemukan lagi dan peran sepenuhya untuk menguraikan bahan organik digantikan oleh mikroorganisme termofilik, kemudian proses dekomposisi akan berjalan sangat lambat yang ditandai dengan perubahan zat-zat organik komplek menjadi cairan koloid. Menurut Rachman (2020) pupuk organik cair yang sudah terdekomposisi dapat dilihat dari penyusutan bahan padatan bahan organik yang menjadi bahan pembuatan pupuk organik cair.

Bahan organik yang terdiri dari protein akan dirombak oleh enzim protease yang bertugas untuk memecah protein. Protein yang terdiri dari asam amino akan dirombak dan menjadi sumber nitrogen yang dapat menyuburkan tanaman. Sementara enzim fitase atau enzim fosfatase bertugas untuk merombak orthofosfat menjadi fosfat yang lebih sederhana dan dapat diserap oleh tanaman (Hidayat, 2006). Dengan berbagai proses perombakan bahan yang terjadi maka tidak heran jika pupuk organik cair mengandung banyak unsur hara yang dapat membantu tanah menyuburkan tanaman.

\section{Pelatihan Pembuatan Desain Produk}

Pupuk organik cair yang telah jadi kemudian disaring dan disimpan didalam ember bersih sebelum dikemas. Selanjutnya warga diberikan pelatihan pembuatan desain produk. Pupuk organik cair ini diberi nama "H2 Super". Hal ini dikarenakan pupuk organik cair tersebut berasal dari dari limbah pasar H2, maka nama $\mathrm{H} 2$ disematkan dalam merek produk. Kata Super sendiri melambangkan harapan masyarakat Desa agar pupuk ini bisa membuat hasil panen mereka menjadi lebih baik lagi hal ini dikarenakan menurut Nur et al. (2010) pupuk organik cair seperti yang dibuat di desa ini yang memanfaatkan dekomposer EM-4 terbukti dapat meningkatkan kandungan Nitogren, Fosfor maupun Corganik serta meningkatkan hasil panen.

Pupuk organik cair ini akan dipasarkan lewat BUMDes dan akan dibuat oleh kelompok tani desa Sido Mukti. Pemasaran pupuk organik cair ini dimulai dari penggunaan warga Desa Sido Mukti. Dengan pemanfaatan yang tepat, sampah organik dari pasar $\mathrm{H} 2$ yang tidak memiliki nilai ekonomis dapat diolah menjadi sesuatu yang memiliki nilai ekonomis tinggi.

\section{Kesimpulan}

Dari kegiatan penyuluhan pembuatan pupuk organik cair ini dapat disimpulkan bahwa peserta penyuluhan sangat tertarik untuk belajar dan memanfaatkan sampah organik menjadi pupuk organik cair. Pembuatan pupuk organik cair ini selain dapat mengurangi sampah organik yang ada di pasar, apabilak pupuk organik cair diaplikasikan ke tanah maka akan menambah kesuburan tanah. Namun agar kegiatan produksi pupuk organik dapat berkelanjutan dan menjadi semakin besar, perlu adanya dukungan dari pemerintah daerah untuk memberikan dukungan baik moriil maupun 
materiil agar warga lebih baik lagi dalam berkarya dan mengembangkan produk pupuk organik cair ini.

\section{Referensi}

Hadisuwito, S. (2007). Membuat pupuk kompos cair. Agromedia Pustaka. Jakarta.

Hidayat, N. (2006). Mikrobiologi industri. Andi offset. Yogyakarta.

Indriani. (2004). Membuat kompos secara kilat. Penebar Swadaya. Jakarta.

Kasmawan, I. G. A., Sutapa, G. N., dan Yuliara, I. M. (2017). Pemberdayaan kelompok lanjut usia melalui pengenalan teknologi pembuatan pupuk organik cair (POC) sebagai upaya bentuk kepedulian terhadap lingkungan. Jurnal Bumi Lestari. 17(2).90-99.

Latifah, R. N., Winarsih, dan Rahayu, Y. S. (2012). Pemanfaatan sampah organik sebagai bahan pupuk cair untuk pertumbuhan tanaman bayam merah (Alternanthera ficoides). Jurnal LenteraBio. 1(3): 139-144.

Marsiningsih, N.W. (2014). Analisis kualitas larutan MOL (mikroorganisme lokal) berbasis ampas tahu. Skripsi. Konsentrasi ilmu tanah dan lingkungan. Fakultas Pertanian Universitas Udayana. Denpasar.
Nur, T., Noor, A. R., \& Elma, M. (2010). Pembuatan pupuk organik cair dari sampah organik rumah tangga dengan penambahan bioaktivator EM4 (Effective Microorganisms). Jurnal Konversi UNLAM. 5(2):5-12.

Rachman, F. (2020). Pembuatan MOL (mikroorganisme lokal). Laporan Praktikum Pupuk dan Teknologi Pemupukan. Jurusan Ilmu Tanah Universitas Lampung. Bandar Lampung.

Rahmah, A., Izzati, M., dan Parman. (2014). Pengaruh pupuk organik cair berbahan dasar limbah sawi putih (Brassica chinensis L.) terhadap pertumbuhan tanaman jagung manis (Zea mays L. var. Saccharata). Buletin Anatomi dan Fisiologi. 12(1):65-71.

Rohani, S., Sirajuddin, S. N., Said, M. I., Mide, M. Z., dan Nurhapsa. (2017). Model pemanfaatan urine sapi sebagai pupuk organik cair Kecamatan Liburen Kabupaten Bone. Jurnal Panrita Abadi. 1(1):11-15.

Salam, A. K. (2012). Ilmu Tanah Fundamental. Global Madani Press. Bandar Lampung. 